\title{
Au-Te Mineralization at Kutyn Gold Deposit, Khabarovsk Region, Russia
}

\author{
ADEL AZARIAN ${ }^{1}$, ELENA BADANINA ${ }^{1}$ AND ILYA \\ ANISIMOV $^{2}$ \\ ${ }^{1}$ St.Petersburg State University \\ ${ }^{2}$ Polymetal Engineering JSC \\ Presenting Author: adel-sagitova@yandex.ru
}

Kutyn gold deposit is located in Khabarovsk Territiry, Russia. Ore bearing zones are localized in the exo- and endo-contact of Late Cretaceous Birandzhinskiy granodioritic massif. Host rocks are Jurassic sandstones.

The ores were presented by sandstones and granodiorites altered into quartz-carbonate-sericite rocks. Some ores were brecciated and oxidized. Modal composition included quartz, albite, orthoclase, sericite, minor carbonates, chlorite and accessory zircon, thorite, tourmaline, apatite, monazite, rutile, anatase, sulfides, tellurides, sulfosalts, goethite, yukonite, scorodite and jarosite.

Based on petrographic and mineralogical study of altered rocks, five ore mineral associations were distinguished.

The first one was presented by finely-disseminated pyrite and arsenopyrite.

The second association could be named as polymetallic and was characterized by formation of massive and porous pyrite, marcasite, sphalerite, chalcopyrite, pyrrhotite, stannite, galena.

The third association was gold-bearing. The prevalent gold form was electrum with the fineness of 680-740\%. Tetrahedrite and Ag-tetrahedrite were wide spread, acanthite and stibnite were rarely found. Arsenopyrite of this stage contained about $1.6 \mathrm{wt}$. $\%$ of Sb. This arsenopyrite was deemed to carry part of gold grades.

The fourth association was telluric. Tellurides were presented by petzite, muthmannite, altaite, hessite, stutzite, tellurantimony $\left(\mathrm{Sb}_{2} \mathrm{Te}_{3}\right)$, coloradoite. The skeletal crystals were typical for arsenopyrite of this stage. Usually the inner parts were free of impurities, but the external parts contained Te.

The oxidation association was presented by the formation of goethite after pyrite and $\mathrm{Ca}-\mathrm{Fe}$-arsenate (yukonite-like phase) and scorodite (observed only in granodiorite-hosted ore) after arsenopyrite. The oxidation of primary gold-bearing pyrite and arsenopyrite was the cause of the occurrence of fine native gold submicronic particles.

As a result, the Kutyn deposit can be classified as gold-quartz low-sulfide. Te-mineralization occured locally.

The reported study was funded by RFBR according to the research project № 20-35-90102 and performed at Geomodel Resource Center, Research park of SPbSU. 